\title{
CLOTHING DESIGN AND ORNAMENT FUNCTION IN THE CONSTRUCTIVIST FASHION OF THE 1920S-1930s
}

Summary: The development of clothing of the 1920s-1930s and its role in the formation of new productivist art are considered in the article. At the beginning of the $20^{\text {th }}$ century, the world underwent not only enormous changes but also the loss of self-identification, both on a personal level and on a social level. The Russian Avant-Garde of the early $20^{\text {th }}$ century became the prototype of not only new art but also claimed to have created a unified system of values. Artists turned their attention to clothing as a new widespread form of language. At the same time, finding a functional application to their creativity was the task. Reconstructing the role of clothing in human life was part of the "life building" concept of the early $20^{\text {th }}$ century. The implementation of this idea was seen in the creation of a universal formula not only for creative work but also for life. The utopian idea of the unification of clothing formed the basis for the creation of anti-class functional working clothes. The project of creating universal clothing for mass production is a vivid example of the practical embodiment of the new productivist art. The search for a new form of dress, as a new cultural code, seemed an extremely attractive idea both from an ideological and artistic point of view. The new concept of universal clothing for work and sports transmitted the idea of creating a person of a new world - the builder of a new life. At the

Changes in the life of society, initiated by the revolutionary turmoil, actualized the need to rethink the role of art; as a result, a discourse on the role of the artist in the new world happened. Constructivists believed that an artist had not so much a craft function as before, but was able to anticipate development trends, "create" ${ }^{1}$ a new world and a new person. The concept of new art, which took on a transforming role, was supposed to have a completely new artistic language, understandable same time, denying fashion as a gender-oriented art form, constructivists tried to use concise forms, avoiding decoration and deliberate embellishment. The creation of innovative clothing for mass production also brings up the subject of the appearance of a new canon of the image of a woman, which changed not only the idea of an aesthetic ideal but also its role in society. At the same time, laboratories, which in their work synthesized the trends and challenges of the new time already existing in the world of Western fashion, were working. An attempt to unite Western fashion trends, national traditions, and mass production can be traced both in the practices of constructivist artists and in the works of artists who collaborated with Atelier of Fashion. New interpretations of folk traditions, as part of the search for self-identity, influenced the inclusion of a number of ornamental techniques in the artistic practices of the early $20^{\text {th }}$ century. On the example of the creative work of V. Stepanova, L. Popova, and N. Lamanova's design, different approaches to the formation of new dress are compared. The article analyzes how the transformation of the approach to clothing design becomes an indicator of sociocultural, political, and ideological changes.

Keywords: working clothes, constructivism fashion, Soviet fashion, Atelier of Fashion.

to a wide range of people. Fashion, as one of the spheres that take over the impulses and demands of society with great speed, became one of those languages with which constructivists expressed their ideas and values. Artists' influence on the development of fashion of that time is a vivid example of the synthesis of arts. Responding to the need for a new visual and semantic code, the fashion had to be completely transformed and even, in a way, be born again.

1. Rodchenko, A. Experiments for the Future. Moscow: Grant 1996. Pp.199-200. 
"Artists stand in front of fashionistas, their forerunners-innovators stand in front of artists..." 2, Bakst wrote in the journal Apollo. Mikhail Larionov, who initiated the fashion trend experimenting with face painting, can be called one of the first innovators. One of the most important thoughts appeared in the Futurism Manifesto: "It's time for art to invade life" 3 . Artists began the realization of new ideas starting with themselves, distinguishing themselves from society through their appearance. The new appearance was a demonstration of a man of a new time. However, Larionov focused on experiments with makeup and with his own clothes whereas his wife, one of the "Amazons of the Russian Avant-Garde" 4 , devoted a lot of time to modern women's clothing. Goncharova's interest in the development of dress can be seen in her sketches created for Natalia Lamanova, a famous Moscow fashion designer, and "Supplier to the Court of Her Imperial Majesty Empress Alexandra Fedorovna" 5 in the past. The sketches that Goncharova created for her were an organic interweaving of national motifs, actual silhouettes and geometric patterns. Russian folk ornaments, for which she had love since childhood, were always an inspiration for her. Goncharova even saw the origins of Cubism in Russian Kurgan stelaes and Russian wooden dolls. Natalia Goncharova's talent was fully revealed after 1913 in work with Diagelev and his Russian seasons. Having left for emigration, she began to interpret Russian motifs in a new way, using their exoticism, which so much attracted Western admirers of her talent. Goncharova's work in the field of fashion was not revolutionary. The artist did not try to reform the dress but brought her signature style to it and, of course, influenced its development.

It is important to say that Lamanova worked not only with Goncharova and other artists, but she herself made a number of major changes in the fashion world of the beginning of the century. After the revolution, in 1919, Nadezhda Lamanova was arrested as an enemy of the proletariat; however, thanks to Maria Andreeva, Maxim Gorky's wife, she was released and continued her career. According to Lamanova's memoirs, the revolution changed her life

2. Bakst, L. S. Ways of Classicism in Art. Apollo. 1909. No. 2-3. P. 47.

3. Zdanevich, I. Why Do We Paint Ourselves. Argus. 1913. No. 12. P. 114.

4. B.K. Livshits [Web resource] URL: http://rusavangard.ru/online/ history/amazonki/ (accessed on 05.20.2020).

5. Avant-Garde-Theater-Fashion. Exposition catalog. Moscow: Severniy Palomnik, 2019. P. 103 but did not change her life ideas. In August 1919, speaking at the first All-Russian Conference on the art industry, she said: "Artists should take the initiative in the field of clothing, work on creating simple, beautiful forms of clothing from simple materials that are suitable for a new working life" ${ }^{6}$.

Obviously, the October Revolution introduced significant changes in the social composition of society. Outfits, luxurious but useless from a labor point of view, inherent in the noble estate, ceased to exist. In general, clothes, as an identifier of special status, were ideologically impossible. The imitation of Western fashion was replaced by the need to create new clothes for the working class. "For Lamanova, with her idea of obligatory matching the dress not only with the external but also with the internal appearance of a person, it was quite natural to think that it was impossible to dress a Russian woman in Parisian fashion. If the nature, climate, lifestyle of Russian life, the physical makeup of people, their spiritual appearance and temperament are different from Western ones, then the appearance of people and their clothing cannot be the same, and Lamanova did not forget that she was working on clothes for a Russian woman" 7 . Nadezhda Lamanova and a group of artists who shared her values actively worked in the laboratories of the State Academy of Art Sciences to create new modern clothes. The national character of the dress, the appeal to national forms, as well as the use of its maximum utilitarianism were the basis of its concept. Artists V. Mukhina and $A$. Exter took the main part in this experiment. The opening of the Atelier of Fashion in 1925 caused great creative debate even before it started working. Even the word "fashion" itself caused many contradictions among the creators, it managed to acquire too bourgeois connotation. Nevertheless, simple dresses made of hopsack with national embroidery were a huge success, as was the fashion show itself. Exceptional functionality, convenience, and elegance were the main features that united all Lamanova's models. The nationality of the dress was emphasized by expressive forms and decorative elements, which often became its center. Embroidery and Old Russian ornament were probably chosen not only due to their aesthetic characteristics but also for their ideological neutrality. Lamanova set

6. Strizhenova, T.K. From the History of the Soviet Costume. Moscow, 1972. P. 17.

7. Temerin, S. M. Russian Applied Art. Soviet Years. Essays. Moscow: Soviet artist, 1960. P. 137. 


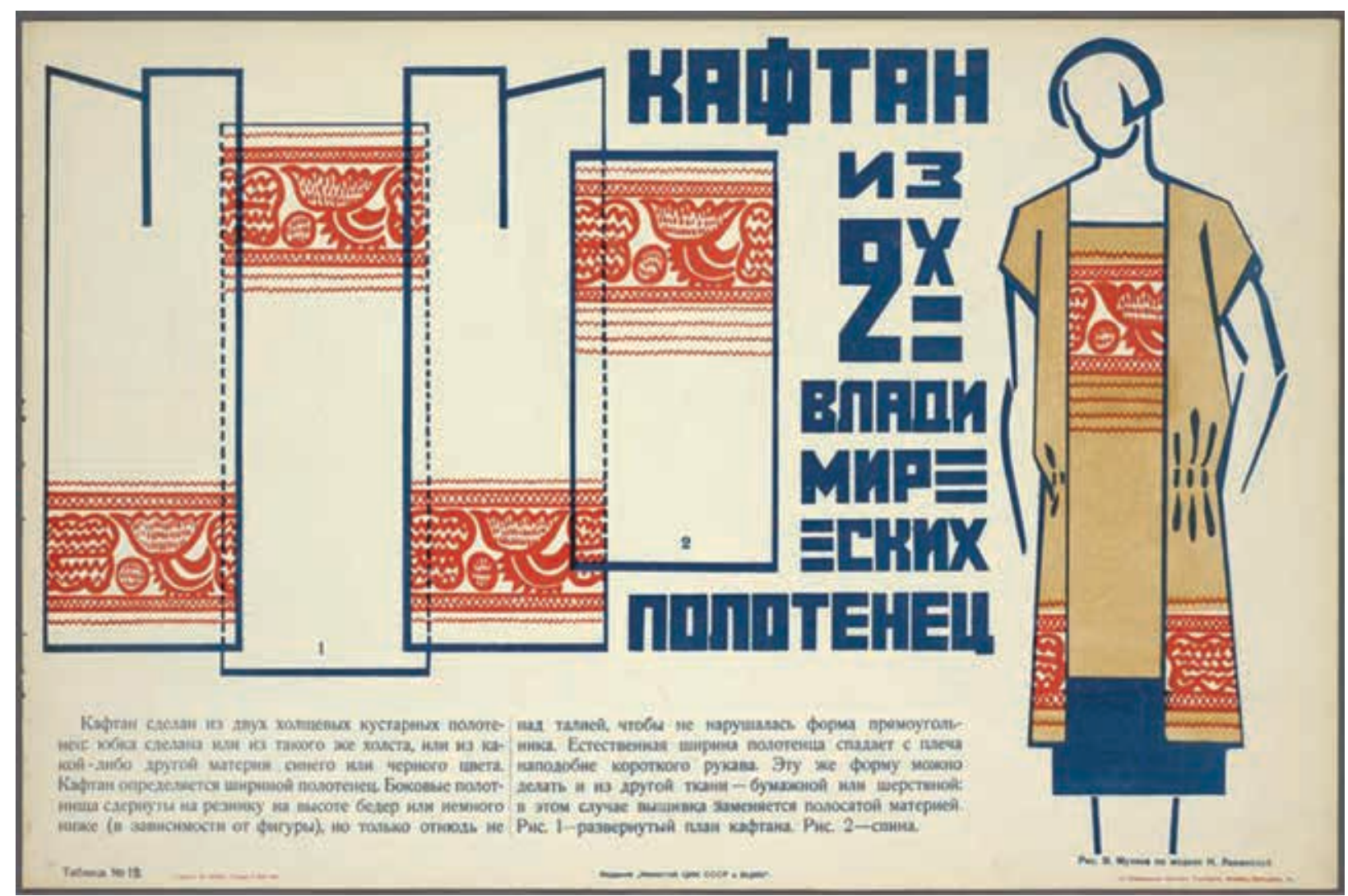

IIl. 1. A page of the album "Art in Life", 1925

herself an extremely difficult task in the conditions of the total deficit. She wanted to make fashion as accessible as possible to all segments of the population. Dress ensembles were created from a limited selection of materials that she could dispose of, namely: linen, homespun wool, semi-bleached linen. Exter also assigned the selection of fabric an important role.

In 1923, Atelier of Fashion under the Moskvoshvey Union published the first and only issue of the Soviet fashion magazine Atelier, which was to become a Soviet alternative to French fashion magazines. The magazine was released in a circulation of 2000 copies and was a great success. The aim of the publication was, of course, to draw attention to the work that was carried out in the Atelier of Fashion. An important place was occupied by the article "On Constructive Clothing" by A. Exter, reflecting the main area of work that was mentioned earlier, namely the requirement of simplicity and functionality. In addition, much attention was paid to the design features of clothes and their aesthetic tasks: "When choosing the form of clothes," the artist wrote, "one must reckon with the natural proportions of the figure; with the help of the correct design of clothing, you can achieve its conformity to the shapes and sizes of the body. Working clothes should ensure freedom of movement, so they cannot be narrowed. One of the main requirements for such clothes is the ease of use" 8 .

The rejection of complex forms (constructivists came to the same idea in painting at that time) was also reflected in Exter's article: "A consumer dress should consist of such simple geometric shapes as a rectangle, a square; the rhythm of color embedded in them will completely diversify the content of the form" ${ }^{\prime}$. Nevertheless, according to the sketches of the artist, we can see that her desire to combine beauty and practicality is visible in her works. Her clothes are functional, often multi-component but by no means devoid of elegance and decoration. In the film Aelita, for which Exter was a dress designer, the artist's imagination and artistic taste are fully demonstrated. The illustration for the cover of Atelier magazine was also created by Exter. And a sketch of the bud-dress of Vera Mukhina is one of the most famous sketches from this magazine. The fluffy drapery of the skirt, the slim waist, and bright black stripes look both traditional and innovative at the same time and, possibly, anticipated the appearance of the new-look silhouette in 1947.

8. [Web resource] URL: https://lobgott.livejournal.com/280930. $\mathrm{html}$ (accessed on 05.19.2020).

9. Ibid. 
In 1925, Lamanova and Mukhina together with artists and constructive architects released the album "Art in Life". The dress pattern album was for ordinary women, not tailors. It is worth emphasizing that this album can be called a real instruction or guide to life in the country of the victorious proletariat. It had everything that a citizen of a new country needed - from a drawing of a hut to a dress pattern. Lamanova and Mukhina created a series of sketches for this album. This series represented the whole range of clothes that the family could need: a school uniform, a tracksuit, a coat, clothes for outside and work. There were twelve pages, among which was a caftan from Vladimir towels and a tunic dress from a scarf.

Despite their emphasized utilitarianism, it should be noted that the works of Lamanova and Mukhina were of compromising nature, they cannot be called adherents of the constructivism ideas of the eradication of aesthetic practices historically associated with clothing. In 1925, the Soviet Union was invited to participate in an international exhibition in Paris. In conditions of severe material shortages, Lamanova and Mukhina were able not only to adequately present their work but to win one of the Grand Prix. At the same exhibition in Paris, the work of two other outstanding artists, V. Stepanova and L. Popova, was presented, which made a significant contribution to the development of Soviet fashion. Their approach to creating modern clothing had significant differences.

Constructivist artists sought, as is known, to fill their works of art with creative meaning, creating them not for influential customers but for the benefit of the people. So Lyubov Popova wrote: "The organization of material means of life is our new goal <...> and all active artistic creativity should be directed in this area" ${ }^{10}$. She considered her artwork to be a preparatory stage for future "constructions" ${ }^{11}$. A beginning was made at the Verbovka studio in 1910. The creator of the studio, Natalya Davydova, was passionate about the promotion of decorative and applied art, and by her order, the embroiderers' artel created a variety of products based on sketches by prominent artists of the time: Exter, Stepanova, Popova, Rozanova and many other avant-garde artists made abstract compositions, and the artisans trans-

10. Adaskina, N. L., Lyubov Popova. The path of Becoming an Artist-Designer. Technical Aesthetics. Moscow, 1978. P. 23.

11. Adaskina, N. L., Lyubov Popova. The path of Becoming an Artist-Designer. Technical Aesthetics. Moscow, 1978. P. 23. ferred them to bags and pillows. Some of them took up this work solely because of the difficult financial situation, for others, household items and clothes were still the same plane for an artistic experiment.

On November 6, 1915, the Exhibition of Contemporary Decorative Art was held in the Lemersie Gallery in Moscow, where works in which traditional crafts were combined with non-objective painting could be seen. These were one of the first avant-garde experiments to introduce art into the subject environment. Undoubtedly, the experience gained during the preparation for the exhibition gave artists the opportunity to experiment in an area that allowed more liberties. Another exhibition of decorative and applied art, which became the last, was held in 1917. Until 1917, Stepanova and Popova were not very passionate about the production of clothing whereas the revolution gave them the opportunity to bring the utopian ideas of constructivism to life. Considering the easel painting being obsolete and useless for the new society, they turned their attention to production, where, in their opinion, their creative potential should have been applied. One of the main slogans of constructivist artists in their work on clothing design was an article by Varvara Stepanova in the 1923 LEF magazine in which she, under the pseudonym Warst, proclaimed: "Working clothes is the clothing of today" ${ }^{12}$. Lamanova's Atelier of Fashion had the task of combining aesthetics and functionality whereas the idea of working clothes was much more radical: "Fashion, which psychologically reflects everyday life, habits, aesthetic taste, gives way to clothes organized for work in various industries" ${ }^{13}$. And one more curious statement: "There is no suit at all, there is a suit for some production function". Clothing, in the opinion of Stepanova and her colleagues, carried an exclusively production function, it was not endowed with other meanings. Aesthetics were not important, only functionality was important. Clothing could change depending on the occupation. Working clothes for various kinds of work and a sports suit differed.

Here several important trends in the development of the dress can be highlighted. The concept of "productionism" was a response to a request for improving the economic situation, and this was a signal to the masses about the image of a new person - the

12. Stepanova, V.F. "Today's Costume is Working Clothes." Lef. 1923. No. 2. [Web resource] http://lamanova.com/16 prozodezhda.html (accessed on 13.05.2020).

13. Ibid. 


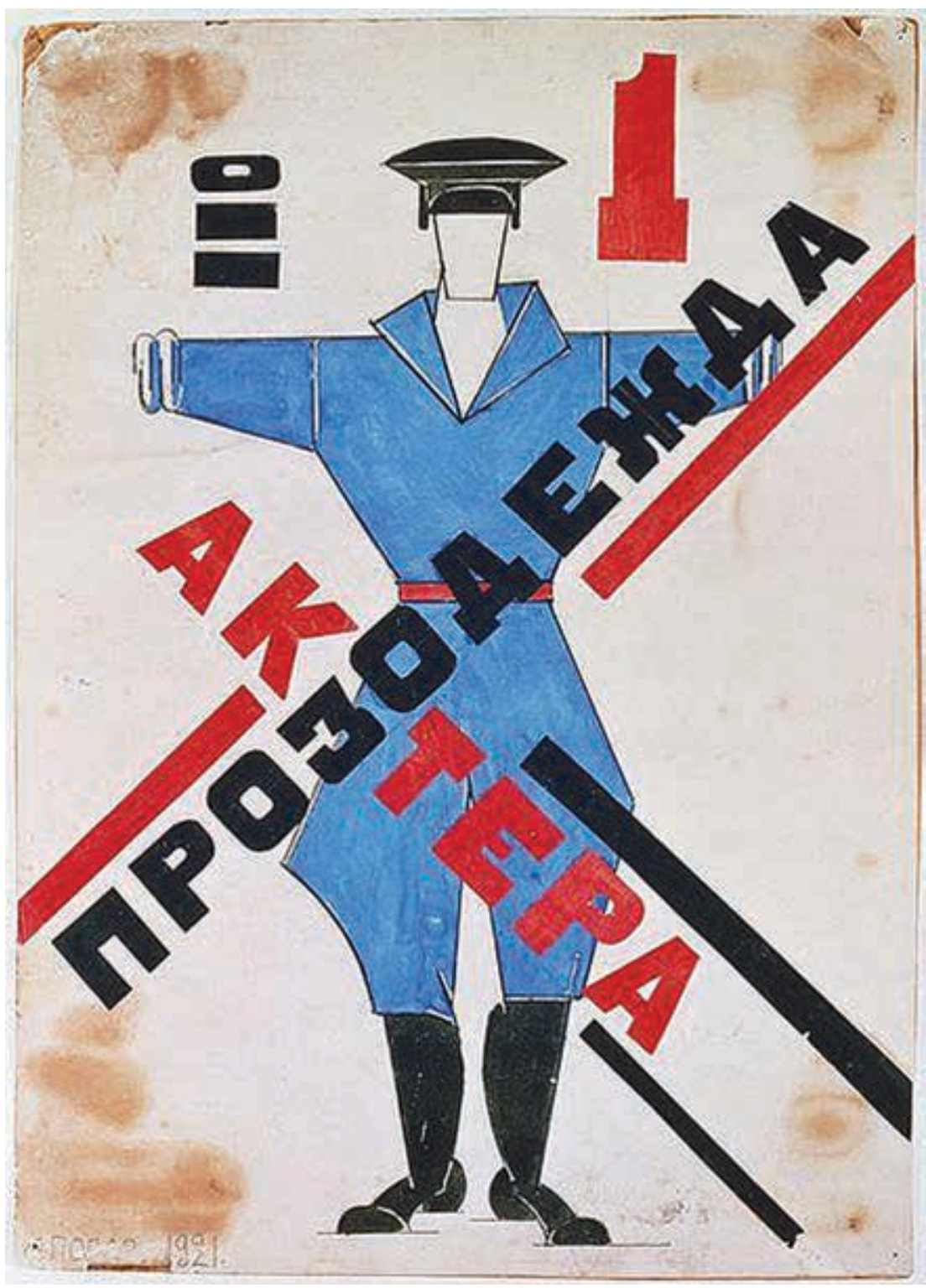

Ill. 2. Projects of Actor's Working Clothes. L. S. Popova. 1922

did not quite correspond to the aesthetic ideas of the constructivists. Popov's visual language, which was also formed in the West, was much wider than the Bolshevik slogans. The aesthetics of cubism, perceived by the artist in France, was taken as a basis in her work on theatrical costumes. It was the theater, which was actively developing in the 1920s, that turned out to be the most suitable place for demonstrating innovative ideas. In 1922, the play Le Cocu Magnifique, for the design of which Popova was invited, was shown on the stage of the Vsevolod Meyerhold Theater. The costumes of the actors were deliberately simple, consisted of the simplest geometric forms and looked like a uniform or working clothes, which was supposed to be for a person employed in the theater. Lyubov Popova wrote that the costume was created " $<\ldots$.. For everyday life and work of an actor, and therefore it was necessary to make it utilitarian for this purpose replacing all other clothes" ${ }^{15}$. The costumes of the heroes that were presented in this performance were similar

builder of a new life. The rationalization of forms of clothing helped create a new work and sport agenda. The formation of new gender roles can also be distinguished as having fundamental importance. The appearance of working clothes, exaggeratedly masculine, constructed the image of a new woman a toiler, dressed in simple and comfortable clothes. It is significant that along with the appearance of the Atelier of Fashion magazine in 1923, the Rabotnitsa ${ }^{14}$ magazine was published. The woman in a red scarf and a work dress depicted on the cover contrasted strongly with Exter's sophisticated illustration. Nevertheless, the image of a strong worker, a woman of the new state, to whom everything bourgeois is alien,

14. Bartlett, J. FashionEast: A Ghost Wandering in Eastern Europe. Trans. from English E. Kardash. Moscow: New Literary Review, 2011. P. 31. in color and material but differed from each other in functional content: the presence of an apron, belt, pockets. Meyerhold's next work was the play The Death of Tarelkin, which the director staged in collaboration with Varvara Stepanova. This performance can also be considered a demonstration of options for working clothes. If we look at each clothing individually, then Tarelkin's clothes were the prototype of the working clothes of an official, the clothes of janitor Pakhom were a uniform of a worker, and Tarelkin's "children" demonstrated examples of sportswear. It was the appearance of sportswear that became one of the most inventive innovations in constructivist fashion. In the catalog for the exhibition Fash-

15. Lavrentiev A.N. "Working Clothes and Fashion" // Artist. Clothes. Fashion: Collection of Articles; comp. M. L. Bodrova, A. N. Lavrentiev. Moscow: Soviet Artist, 1988. P. 63. 
ion for the People! From Constructivism to Design, A. Lavrentyev called the appearance of mass sportswear "a symbol of liberation" ${ }^{16}$. Stepanova's working clothes had a strict geometric shape and had an almost identical base, like Popova's, changing under the influence of functional tasks. A decorative role was played by contrasting seams, fasteners, and color blocks. In the sketches for the play, the motif of stripes can be seen, for example, in the costume of Mavrusha, Tarelkin, and others. Later, this motif became one of the main ones in her work with fabrics.

In 1923, the Dean of VKHUTEMAS, Professor Viktorov, wrote a letter to the newspaper Pravda and asked artists to respond to the needs of the industry. Popova and Stepanova responded to this call and became textile designers. Despite the experience in the field of arts and crafts, the artists faced a completely new task. The textile industry set before them the goals not only to decorate clothes with the artistic techniques known to them but to bring "an artistic moment to the principle of creating the most utilitarian piece of clothing" ${ }^{17}$. The complexity of this work was determined by many factors. In working with fabrics, artists had to combine their own visual ideas, the specifics of production, as well as the ideological ideas of Constructivism. In addition, the economic situation required a reduction in funds for production. Textile experiments by Stepanova and Popova met all the necessary requirements. In their drawings, they used no more than four colors, which made production economical. They created fabrics with objectless suprematist designs that contrasted very much with the predominantly floral textiles of the previous period. Thus, the task of updating the assortment was fulfilled, since floral ornaments were associated with the "bourgeois" way of life and did not correspond to the new reality.

Stepanova and Popova began to work with great enthusiasm. "She (Popova) sat days and nights over the drawings, trying to combine the requirements of the economy, the laws of external design, and the mysterious taste of a Tula peasant woman in a single creative act" ${ }^{18}$. Since Lyubov Popova focused on ordinary people in her works, the appeal for inspi-

16. Avant-Garde-Theater-Fashion. Exposition catalog. Moscow: Northern Pilgrim, 2019. P. 150.

17. Khan-Magomedov S. O. Pioneers of Soviet Design. Moscow: Galart, 1995. P. 97

18. "In memory of L. S. Popova" // LEF. 1924. No. 2. [Web resource] URL: http://www.ruthenia.ru/sovlit/j/2970.html (accessed on 05.19.2020). ration to folk roots was quite logical. Many of the artist's drawings can be interpreted as a combination of her own artistic ideas with peasant traditions. Ornamental inserts that can be seen on Popova's sketches are similar to the models of Nadezhda Lamanova's dresses. Popova takes the circle as the basis of her many drawings, modifying and combining it with the simplest geometric forms. With seeming simplicity, they are surprisingly diverse, and in addition, they are exclusively innovative in nature, the entire scale of which could only be appreciated by the contemporaries of the artist. Despite perhaps a radical innovation, Popova clearly managed to "guess the chintz" ${ }^{19}$, in the summer of 1924, these fabrics were very popular. Jacob Tugenhold wrote that "last spring [1925. - Comp.], all Moscow, not knowing it, was wearing fabrics according to Popova's drawings, drawings that were bright, sharp, full of movement, like the nature of the artist herself" 20 .

Varvara Stepanova's textile sketches are close to the works of Popova based on the artistic style; however, they certainly differ in character and overall impression. Lyubov Popova was passionate about finding a universal method of work that would help create the greatest variety of textile options, which explains her incredible productivity. Stepanova's work was meticulously verified with a ruler and compass. In her textile works, we again meet the motif of a stripe, in various interpretations, layering circles, as well as many other artistic techniques. The artistic techniques of Stepanova and Popova, as mentioned earlier, were unconditionally innovative. A rare artifact that allows us to appreciate this is footage from the film A Cigarette Box from Moselprom, which was released in 1924. A dress with art by Varvara Stepanova definitely looks like a thing from another world, contrasting significantly with the situation. The attention of the artists was riveted not only to the drawings themselves but also to the specifics of the textile, as such. Stepanova believed that the artist should be involved in the production of fabric at all levels.

Unfortunately, many plans were not destined to come true. Already in the early 1930s, the work of constructivists was increasingly criticized and replaced by the propaganda textiles of Socialist Realism. In addition, despite the manifestos and attitudes, no matter how hard the artists tried to deny the

19. Tulovskaya, Y.A. Avant-Garde Textiles. Drawings for Fabric. Yekaterinburg: TATLIN, 2016. P. 51.

20. Ibid. 
role of fashion in society, the artist prevailed over the production worker in the process of creativity, and excessive unification faced a number of contradictions. Perhaps the words of Varvara Stepanova in 1929 are connected with this: "It is a mistake to think that fashion is only an unnecessary appendage of a speculative nature" ${ }^{21}$.

21. Strizhenova, T.K. From the History of the Soviet Costume. Moscow: Soviet Artist, 1972. P. 97.
The idea of the Avant-Garde on the existence of an artist-creator capable of creating a new system of life was not brought to an end but perhaps completely failed. Nevertheless, the experiments of the "Amazons of the Avant-Garde" in the field of fashion play an extremely important role, both for the art history and for the history of fashion. References to their ideas were massively reproduced in the 1960s, and in addition, they still appear on podiums, inspiring artists in all areas of art.

\section{REFERENCES}

1. Adaskina, N. L. 1978. "Lyubov' Popova. Put' stanovleniya khudozhnikom-dizaynerom" ["Lyubov Popova. The path of Becoming an Artist-Designer"], Tekhnicheskaya estetika [Technical Aesthetics], no. 10, pp. 17-23. (in Russian)

2. Amazonki avangarda [Amazons of the Avant-Garde]. Collection of articles edited by G. F. Kovalenko. Moscow: Nauka, 2001. P. 338. (in Russian)

3. Avangard-teatr-moda [Avant-Garde-Theater-Fashion]. Exposition catalog. Moscow: Severniy Palomnik, 2019. (in Russian)

4. Bakst, L. S. 1909. "Puti klassitsizma v iskusstve" ["Ways of Classicism in Art"], Apollon [Apollo], no. 2-3.

5. Bartlett, J. 2011. [FashionEast: prizrak, brodivshiy po Vostochnoy Yevrope] FashionEast: A Ghost Wandering in Eastern Europe. Moscow, p.356. (in Russian)

6. Gorbova, E. N. 2012. "Idei zhizni russkogo avangarda v estetike rabochey odezhdy. Proyekt nachala XX veka " ["The Ideas of the Russian Avant-Garde Life in the Aesthetics of the Working Clothes. Project of the Beginning of the $20^{\text {th }}$ Century"], Vestnik Kazanskogo gosudarstvennogo universiteta kul'tury i iskusstv [Bulletin of Kazan State University of Culture and Arts], no. 1-3, pp. 52-55. (in Russian)

7. Khan-Magomedov, S. O. 1995. Pionery sovetskogo dizayna [Pioneers of Soviet Design]. Moscow, p. 442. (in Russian)

8. Lavrentiev, A. N. 1988. "Rabochaya odezhda i moda" ["Working Clothes and Fashion"], Khudozhnik. Odezhda. Moda: Sbornik statey [Artist. Clothes. Fashion: Collection of articles], Moscow, p. 366. (in Russian)

9. Adaskina, N. L., Krasnyanskaya, K. \& Kostaki, A. 2019. Lyubov' Popova. Forma. Tsvet. Kosmos [Lyubov Popova. Form. Colour. Space], Moscow, p. 256, ill. 256. (in Russian)

10. In memory of L. S. Popova. [Obituary], LEF. No. 2. 1924. pp. 3-4. (in Russian)
11. Rodchenko, A. 1996. Eksperimenty na budushcheye [Experiments for the Future]. Moscow, p. 416. (in Russian)

12. Stepanova, V. F. 1923. "Segodnyashniy kostyum rabochaya odezhda" ["Today's Costume is Working Clothes"], LEF. no. 2. Available at: http://www.ruthenia.ru/moskva/origins/design/varst.htm (accessed: 05.06.2020) (in Russian)

13. Strizhenova, T. K. 1972. Iz istorii sovetskogo kostyuma [From the History of the Soviet Costume], Moscow, p. 110. (in Russian)

14. Temerin, S. M. 1960. Russkoye prikladnoye iskusstvo. Sovetskiye gody. Esse [Russian Applied Art. Soviet Years. Essays]. Moscow, p. 458. (in Russian)

15. Tulovskaya, Y. A. 2016. Avangardnyy Tekstil'. Risunki dlya tkani [Avant-Garde Textiles. Drawings for Fabric], Yekaterinburg: TATLIN, p. 173. (in Russian)

16. Zdanevich, I. 1913. "Pochemu my raskrashivayemsya" ["Why Do We Paint Ourselves"], Argus. no. 12, pp. 115118. (in Russian)

17. Bartlett, D. 2017. "Léon Bakst and Fashion: Beyond and After the Ballets Russes", Costume, vol. 52, no. 2, pp. 210-234 DOI: 10.3366/cost.2017.0025 (in English)

18. Tiramani, J. 2015. "Janet Arnold's Patterns of Fashion", Costume, vol. 49, no. 2, pp. 186-197 DOI: 10.1179/0590887615z.00000000075 (in English)

19. Ng, S. 2015. "Gendered by Design: Qipao and Society, 1911-1949", Costume, vol. 49, no. 1, pp. 55-74 DOI: 10.1179/0590887614z.00000000063 (in English)

20. Pecorari, M. 2019." Fashion archives, museums and collections in the age of the digital", Critical Studies in Fashion \& Beauty, vol. 10, no. 2, pp. 3-29 DOI: 10.1386/ csfb.10.1.3_7 (in English)

21. Kuldova, T. 2014." Fashion exhibition as a critique of contemporary museum exhibitions: The case of 'Fashion India: Spectacular Capitalism", Critical Studies in Fashion \& Beauty, vol.5, no. 2, pp. 313-336 DOI: 10.1386/csfb.5.2.313_1 (in English) 


\section{ДИЗАЙН КОСТЮМА И ФУНКЦИЯ ОРНАМЕНТА В КОНСТРУКТИВИСТСКОЙ МОДЕ 1920-1930-Х ГОДОВ}

Аннотация: В статье рассматриваются развитие костюма 1920-1930-х годов и его роль в формировании нового производственного искусства. В начале XX века мир претерпевал не только колоссальные изменения, но и потерю самоидентификации - как на личностном уровне, так и на общественном. Русский авангард начала XX века стал прообразом не только нового искусства, но и претендовал на создание единой системы ценностей. Художники обратили своё внимание на одежду как на новую форму языка, имеющую большое распространение. Наряду с этим ставилась задача найти функциональное применение своему творчеству. Переконструирование роли одежды в жизни человека являлось частью концепции «жизнестроительства» начала XX века. Реализация этой идеи виделась в создании универсальной формулы не только для творчества, но и для жизни. Утопическая идея об унификации одежды легла в основу создания антисословной и функциональной «прозодежды». Проект создания универсального костюма для массового производства является ярким примером практического воплощения нового производственного искусства. Поиск новой формы костюма как нового культурного кода казался крайне привлекательной идеей - как с идеологической, так и с художественной точки зрения. Новая концепция универсальной одежды для труда и спорта транслировала идею создания человека

Инициированные революционными потрясениями изменения жизни общества актуализировали необходимость переосмысления роли искусства, вследствие которого возник дискурс о роли художника в новом мире. Конструктивисты считали, что художник несёт в себе не только ремесленную функцию, как ранее, но и способен предвосхищать тенденции развития, «сотворить» ${ }^{1}$

1. Родченко А. Опыты для будущего. М., 1996. С. 199-200. нового мира - строителя новой жизни. Вместе с тем, отрицая моду как гендерно ориентированный вид искусства, конструктивисты старались использовать лаконичные формы, избегая декорирования и нарочитого украшательства. Создание новаторского костюма для массового производства также затрагивает тему появления нового канона образа женщины, что меняло не только представление об эстетическом идеале, но и её роль в жизни общества. В то же время работали лаборатории, синтезирующие в своём творчестве уже существующие в мире западной моды тенденции и вызовы нового времени. Попытка объединения западных модных течений, национальных традиций и массового производства прослеживается как в практиках художников-конструктивистов, так и в работах художниц, которые сотрудничали с Ателье мод. Новые интерпретации народных традиций как часть поиска самоидентичности повлияли на включение ряда орнаментальных приёмов в художественные практики начала XX века. На примере творчества В. Степановой, Л. Поповой и дизайна Н. Ламановой произведено сравнение разных подходов к формированию нового костюма. В статье проанализировано, как трансформация подхода к дизайну одежды становится индикатором социокультурных, политических и мировоззренческих перемен.

Ключевые слова: прозодежда, мода конструкти визма, советская мода, Ателье мод.

новый мир и нового человека. Концепция нового искусства, которая брала на себя трансформирующую роль, должна была обладать совершенно новым художественным языком, понятным широкому кругу людей. Мода как одна из сфер, которая с большой скоростью перенимает импульсы и запросы общества, стала одним из тех языков, с помощью которого конструктивисты выражали свои идеи и ценности. Влияние художников на развитие моды того времени является ярким 
примером синтеза искусств. Откликнувшись на потребность в новом визуальном и смысловом коде, мода должна была полностью трансформироваться и даже в некотором смысле родиться заново.

«Впереди модниц идут художники, впереди художников идут их предтечи-новаторы...» ${ }^{2}$, - писал Бакст в журнале «Аполлон». Одним из первых новаторов можно назвать Михаила Ларионова, зародившего модную тенденцию, экспериментируя с раскрашиванием лица. В «Манифесте футуризма» прозвучала важнейшая мысль: «Пора искусству вторгнуться в жизнь» ${ }^{3}$. Претворение новых идей художники начинали с себя, выделяя себя из общества посредством внешнего вида. Новый внешний вид являлся демонстрацией человека нового времени. Но если Ларионов был сосредоточен на экспериментах с гримом и собственной одеждой, то его супруга и одна из «амазонок русского авангарда» ${ }^{4}$ много времени уделяла современному женскому костюму. Интерес Гончаровой к развитию костюма можно увидеть в её эскизах, созданных для Натальи Ламановой - известного московского модельера, а в прошлом - «Поставщицы двора Ея императорского Величества Императрицы Александры Фёдоровны» 5 . Эскизы, которые Гончарова для неё создавала, являли собой органичное переплетение национальных мотивов, актуальных силуэтов и геометрических узоров. Любовь к русским народным орнаментам, которую она питала с детства, всегда была источником вдохновения для её творчества. Даже истоки кубизма Гончарова видела в наших скифских каменных бабах и русских деревянных куклах. Талант Натальи Гончаровой в полной мере раскроется после 1913 года в работе с Дягилевым и его «Русскими сезонами». Уехав в эмиграцию, она по-новому станет интерпретировать русские мотивы, используя их экзотичность, которая так сильно будет привлекать западных почитателей её таланта. Работа Гончаровой в области моды не носила революционный характер. Художница не пыталась реформировать костюм, но привнесла в него свой фирменный стиль и, безусловно, повлияла на его развитие.

2. Бакст Л.С. Пути классицизма в искусстве // Аполлон. 1909. № 2-3. С. 47.

3. Зданевич И., Ларионов М. Почему мы раскрашиваемся // Аргус, 1913. № 12. С. 114

4. Цит. По: Лившиц Б.К. [Сетевой ресурc]URL: http:// rusavangard.ru/online/history/amazonki (дата обращения: 20.05.2020).

5. Авангард-театр-мода. Каталог экспозиции. М.: Северный паломник, 2019. С. 103.
Важно сказать, что Ламанова работала не только с Гончаровой и другими художниками, но и сама совершила ряд важнейших изменений в мире моды начала века. После революции, в 1919 году Надежда Ламанова была арестована как враг пролетариата, но благодаря Марии Андреевой, жене Максима Горького, была освобождена и продолжила свой творческий путь. По воспоминаниям самой Ламановой, революция изменила её жизнь, но не изменила её жизненных идей. В августе 1919 года, выступая на первой Всероссийской конференции по художественной промышленности, она говорила: «Художники должны в области одежды взять инициативу в свои руки, работая над созданием из простых материалов простейших, но красивых форм одежды, подходящих к новому укладу трудовой жизни» 6 .

Очевидно, что Октябрьская революция внесла значительные изменения в социальный состав общества. Роскошные, но бесполезные с трудовой точки зрения наряды, присущие дворянскому сословию, перестали существовать. В целом, одежда, как идентификатор особого статуса, была идеологически невозможна. Актуальное до этого момента подражание западной моде сменилось необходимостью создать новый костюм для рабочего класса. «Для Ламановой, с её идеей обязательного соответствия костюма не только внешнему, но и внутреннему облику человека, вполне естественным был приход к мысли о невозможности одевать русскую женщину по парижским модам. Если природа, климат, уклад русской жизни, физический склад людей, их духовный облик и темперамент отличны от западных, то и внешний облик людей и их костюм не могут быть одинаковы, и Ламанова не забывала, что она работает над костюмом для русской женщины» ${ }^{7}$. Надежда Ламанова и группа художниц, разделявших её ценности, вели активную работу в лабораториях Государственной академии художественных наук по созданию нового современного костюма. Основой его концепции была народность костюма, обращение к национальным формам, а также использование его максимальной утилитарности. Основное участие в этом эксперименте приняли художницы В. Мухина и А. Экстер. Открытие в 1925 году

6. Стриженова Т. К. Из истории советского костюма. М., 1972. С. 17.

7. Темерин С.М. Русское прикладное искусство. Советские годы. Очерки. М.: Советский художник, 1960. С. 137. 
Ателье мод вызвало большие творческие споры ещё до начала его работы. Даже само слово «мода» вызывало много противоречий у создателей - слишком буржуазную коннотацию оно успело приобрести. Тем не менее простые платья из рогожки с национальной вышивкой имели огромный успех, как и сам показ советских мод. Основными чертами, которые объединяли все модели Ламановой, стали исключительная функциональность, удобство и элегантность. Народность костюма подчёркивалась выразительными формами и декоративными элементами, которые нередко становились её центром. Вышивка и древнерусский орнамент вероятно были выбраны не только благодаря своим эстетическим характеристикам, но и за свою идеологическую нейтральность. Ламанова ставила перед собой исключительно сложную в условиях тотального дефицита задачу. Она хотела сделать моду максимально доступной всем слоям населения. Костюмные ансамбли были созданы из ограниченного выбора материалов, которыми она могла распоряжаться, а именно: лён, домотканая шерсть, полуотбелённое полотно. Важную роль к подбору ткани отводила и Экстер.

В 1923 году Ателье мод при объединении «Москвошвея» выпустило в свет первый и единственный выпуск советского журнала мод «Ателье», который должен был стать советской альтернативой французским журналам мод. Журнал был выпущен тиражом 2000 экземпляров и имел большой успех. Издание, конечно же, должно было привлечь внимание к той работе, которая велась в Ателье мод. Важное место занимала статья А. Экстер «О конструктивной одежде», отражающая основное направление работы, о котором говорилось ранее, а именно - требование простоты и функциональности. Кроме этого, большое внимание было уделено конструктивным особенностям одежды и её эстетическим задачам: «При выборе формы одежды, - писала художница, - следует считаться с естественными пропорциями фигуры; с помощью правильного конструирования одежды можно добиться её соответствия формам и размерам тела. Рабочая одежда должна обеспечить свободу движений, поэтому она не может быть зауженной. Одно из главных требований к такому костюму - удобство в работе» ${ }^{8}$.

8. [Сетевой ресурс] URL: https://lobgott.livejournal.com/280930. html (дата обращения: 19.05.2020).
Отказ от сложных форм, к которому в это время приходили конструктивисты в живописи, также нашёл отражение в статье Экстер: «Костюм широкого потребления должен состоять из таких простейших геометрических форм, как прямоугольник, квадрат; ритм цвета, вложенный в них, вполне разнообразит содержание формы» ${ }^{9}$. Тем не менее по эскизам художницы мы можем видеть, что в её работах видно её желание соединять красоту и практичность. Её костюмы функциональны, часто многосоставны, но отнюдь не лишены элегантности и украшательства. А в фильме «Аэлита», для которого Экстер выступила художником по костюмам, в полной мере демонстрируются фантазия и художественный вкус художницы. Иллюстрацию для обложки журнала «Ателье» также создала Экстер. А одним из самых знаменитых эскизов из этого журнала станет эскиз платья-бутона Веры Мухиной. Пышная драпировка юбки, тонкая талия и яркие чёрные полосы выглядят одновременно традиционно и новаторски и, возможно, предвосхищают появления силуэта new look в 1947 году.

В 1925 году Ламанова и Мухина совместно с художниками и архитекторами-конструктивистами выпускают альбом «Искусство в быту». Альбом с выкройками предназначался для обычных женщин, а не для портних. Надо сказать, что этот альбом можно назвать настоящей инструкцией или руководством к жизни в стране победившего пролетариата. В нём было всё, что необходимо гражданину новой страны, - от чертежа избы до выкройки платья. Ламанова и Мухина создали для этого альбома серию эскизов. Эта серия представляла весь спектр одежды, которая могла понадобиться семье: школьная форма, спортивный костюм, пальто, костюм для улицы и работы. Всего 12 страниц, среди которых были кафтан из владимирских полотенец и платье-туника из платка.

Несмотря на подчёркнутую утилитарность, нельзя не отметить, что работы Ламановой и Мухиной носили компромиссный характер, - их нельзя назвать приверженцами идей конструктивизма об искоренении эстетических практик, исторически связанных с одеждой. В 1925 году Советский Союз был приглашён к участию в международной выставке в Париже. Ламанова и Мухина, в условиях тяжёлого дефицита материала, смогли не только достойно представить свои

9. Там же. 
работы, но и завоевать один из grand-prix. На этой же выставке в Париже было представлено творчество двух других выдающихся художниц, которые внесли значительный вклад в развитие советской моды, а именно В. Степановой и Л. Поповой. Их подходы к созданию современного костюма имели значительные различия.

Художники-конструктивисты стремились, как известно, наполнить свои произведения созидательным смыслом, создавая их не для влиятельных заказчиков, а на благо народа. Так, Любовь Попова писала: «Нашей новой целью является организация материальных средств жизни <...> на эту область и должно быть направлено всё активное художественное творчество» ${ }^{10}$. Свои художественные работы она считала подготовительным этапом для будущих «конструкций» ${ }^{11}$. Начало этому было положено в 1910 году в ателье «Вербовка». Создательница ателье Наталья Давыдова была увлечена продвижением декоративно-прикладного искусства, и по её заказу артель вышивальщиц создавала самые разные изделия по эскизам выдающихся художников того времени: Экстер, Степанова, Попова, Розанова и многие другие авангардисты делали абстрактные композиции, а мастерицы артели переносили их на сумки и подушки. Некоторые из них брались за эту работу исключительно из-за сложной финансовой ситуации, для других же предметы быта и одежды были всё той же плоскостью для художественного эксперимента.

В Москве 6 ноября 1915 года в галерее Лемерсье прошла «Выставка современного декоративного искусства», на которой можно было увидеть работы, где традиционные ремёсла сочетались с беспредметной живописью. Это были одни из первых опытов авангарда по внедрению искусства в предметную среду. Бесспорно, опыт, полученный во время подготовки к выставке, дал художницам возможность поэкспериментировать в той области, которая позволяла больше вольностей. Ещё одна выставка ДПИ была проведена в 1917 году, она же и стала последней. Если до 1917-го Степанова и Попова не были сильно увлечены производством одежды, то революция дала им возможность воплотить утопические идеи конструктивизма в жизнь. Считая

10. Адаскина Н. Любовь Попова. Путь становления художника-конструктора//Техническая эстетика. № 10. М.: ВНИИЭТЭ, 1978. С. 23.

11. Там же. станковую живопись отжившей и бесполезной для нового общества, они обратили своё внимание именно на производство, где, по их мнению, должен был найти применение их творческий потенциал. Одним из главных лозунгов художников-конструктивистов в их работе над дизайном одежды станет статья Варвары Степановой в журнале «ЛЕФ» 1923 года, в котором она, под псевдонимом Варст, провозглашала: «Костюм сегодняшнего дня - прозодежда» ${ }^{12}$. Если в Ателье мод Ламановой стояла задача совместить эстетику и функциональность, то идея прозодежды была куда более радикальна: «Мода, психологически отражавшая быт, привычки, эстетический вкус, уступает место одежде, организованной для работы в различных отраслях труда» ${ }^{13}$. И ещё одно любопытное высказывание: «Нет костюма вообще - есть костюм для какой-нибудь производственной функции». Одежда, по мнению Степановой и её коллег, несла исключительно производственную функцию, другими смыслами она не наделялась. Эстетика была не важна важна только функциональность. Одежда могла видоизменяться в зависимости от рода занятий. Различались спецодежда для разного рода работы и спортивный костюм.

Здесь мы можем выделить несколько важных тенденций развития костюма. Концепция «производничества» являлась ответом на запрос об улучшении экономической ситуации, и это был сигнал народным массам об образе нового человека - строителя новой жизни. Рационализация форм одежды помогала создавать новую повестку дня - труд и спорт. Формирование новых гендерных ролей также можно выделить как имеющее принципиально важный характер. Появление «прозодежды», подчёркнуто маскулинной, конструировало образ новой женщины-труженицы, одетой в простую и удобную одежду. Показательно, что наряду с появлением журнала «Ателье мод» в 1923 году был издан журнал «Работница» ${ }^{14}$. Женщина в красном платке и рабочем платье, изображённая на обложке, сильно контрастирует с утончённой иллюстрацией Экстер. Тем не менее образ крепкой работницы -

12. Степанова В.Ф. Костюм сегодняшнего дня - прозодежда. // Леф. 1923. Цит. по. [Сетевой ресурc] URL: http://lamanova. com/16_prozodezhda.html (дата обращения: 13.05.2020).

13. Там же.

14. Бартлетт, Дж. FashionEast: призрак, бродивший по Восточной Европе / Дж. Бартлет; пер. с англ. Е. Кардаш. М.: Новое литературное обозрение, 2011. С. 31. 
женщины нового государства, которой чуждо всё буржуазное, - не совсем отвечал эстетическим представлениям конструктивистов. Визуальный язык Поповой, сформированный в том числе и на Западе, был значительно шире большевистских лозунгов. Эстетика кубизма, воспринятая художницей во Франции, была взята за основу в её работе над театральными костюмами. Именно театр, который активно развивался в 1920-е годы, оказался самым подходящим местом для демонстрации новаторских идей. В 1922 году на сцене театра имени Всеволода Мейерхольда был показан спектакль «Великодушный рогоносец», для оформления которого была приглашена Л. Попова. Костюмы актёров были нарочито просты, состояли из простейших геометрических форм и были похожи на униформу или «прозодежду», которая полагалась человеку, занятому в театре. Любовь Попова писала, что костюм создавался «<...> для каждодневной и обыденной жизни и работы актёра, и поэтому необходимо было сделать его утилитарным и для этой цели и заменяющим всякую другую одежду» ${ }^{15}$. Костюмы героев, которые были представлены в этом спектакле, были похожи по цвету и материалу, но отличались друг от друга функциональным наполнением: наличием фартука, ремня, карманов. Следующей работой Мейерхольда стал спектакль «Смерть Тарелкина», который режиссёр поставил в сотрудничестве с Варварой Степановой. Этот спектакль также можно считать демонстрацией вариантов «прозодежды». Если рассмотреть каждый костюм в отдельности, то костюм Тарелкина был прототипом «прозодежды» чиновника, костюм дворника Пахома представлял собой униформу рабочего, а «дети» Тарелкина демонстрировали образцы спортивной одежды. Именно появление спортивной одежды стало одним из самых новаторских нововведений конструктивистской моды. В каталоге к выставке «Мода - народу! От конструктивизма к дизайну» А. Лаврентьев назвал появление массовой спортивной одежды «символом освобождения» ${ }^{16}$. Прозодежда Степановой обладала строгой геометрической формой и имела практически идентичную основу, так же, как и у Поповой, видоизменяясь под влиянием функциональных задач. Декоративную роль ис-

15. Лаврентьев А.Н. Производственный костюм и мода // Художник, вещь, мода: Сб. статей / Сост. М.Л. Бодрова, А.Н. Лаврентьев. М.: Сов. художник, 1988. С. 63.

16. Цит. По: Авангард-театр-мода. Каталог экспозиции. М.: Северный паломник, 2019. С. 150. полняли контрастные швы, застёжки и цветовые блоки. В эскизах к спектаклю можно увидеть мотив полос, например в костюмах Мавруши, Тарелкина и других. Позже этот мотив станет одним из основных в её работе с тканями.

В 1923 году декан ВХУТЕМАСА профессор Викторов написал письмо в газету «Правда» и попросил художников откликнуться на нужды промышленности. Попова и Степанова отозвались на этот призыв и стали текстильными проектировщиками. Несмотря на наличие опыта в области декоративно-прикладного искусства, перед художницами стояла совершенно новая задача. Текстильная промышленность ставила перед ними цели не просто украсить одежду известными им художественными приёмами, но привнести «художественный момент в принцип создания самой утилитарной вещи» ${ }^{17}$. Сложность этой работы обуславливалась множеством факторов. В работе с тканями художницам необходимо было соединить собственные визуальные идеи, специфику производства, а также идеологические идеи конструктивизма. Кроме того, экономическая ситуация требовала сокращения средств на производство. Текстильные эксперименты Степановой и Поповой отвечали всем необходимым запросам. В своих рисунках они использовали не больше четырёх цветов, что делало производство экономным. Они создавали ткани с беспредметными супрематистскими рисунками, которые очень контрастировали с преимущественно цветочным текстилем предыдущего периода. Тем самым была выполнена задача по обновлению ассортимента, так как цветочные орнаменты ассоциировались с «буржуазным» бытом и не соответствовали новой реальности.

В. Степанова и Л. Попова приступили к работе с большим энтузиазмом. «Дни и ночи просиживала она (Попова) над рисунками, стараясь в едином творческом акте сочетать требования экономии, законы внешнего оформления и таинственный вкус тульской крестьянки» ${ }^{18}$. Так как в своих работах Любовь Попова ориентировалась на простых людей, обращение за вдохновением к народным корням было вполне логичным. Многие рисунки художницы могут интерпретироваться как соединение её собственных художественных

17. Пионеры советского дизайна / С. О. Хан-Магомедов. - М.: Галарт, 1995. С. 97.

18. Памяти Л.С. Поповой // ЛЕФ. 1924. № 2. [Сетевой ресурс] URL: http://www.ruthenia.ru/sovlit/j/2970.html (дата обращения: 19.05.2020) 
идей с крестьянскими традициями. Орнаментальные вставки, которые можно увидеть на эскизах Поповой, схожи с моделями платьев Надежды Ламановой. За основу множества своих рисунков Попова берёт круг, модифицируя и комбинируя его с простейшими геометрическими формами. При кажущейся простоте они удивительно разнообразны, а кроме того, носят исключительно новаторский характер, весь масштаб которого могли оценить только современники художницы. Несмотря на, возможно, радикальное новаторство, Поповой явно удавалось "угадать ситчик» ${ }^{19}$ - летом 1924 года эти ткани пользовались большой популярностью. Яков Тугенхольд писал, что «минувшей весной [1925. - Сост.] вся Москва носила ткани по рисункам Поповой, не зная этого, - рисункам ярким, резким, полным движения, как натура самой художницы» 20.

Текстильные эскизы Варвары Степановой близки к работам Поповой и по художественному стилю, но безусловно, отличаются по характеру и общему впечатлению. Любовь Попова была увлечена поиском универсального метода работы, который помог бы создать наибольшее разнообразие вариантов текстиля, что объясняет её невероятную продуктивность. Работы Степановой скрупулёзно выверены с помощью линейки и циркуля. В её текстильных работах мы снова встречаем мотив полосы в различных интерпретациях, наслоение кругов, а также множество других художественных приёмов. Художественные приёмы Степановой и Поповой, как говорилось ранее, носили безусловно новаторский характер. Редким артефактом, который позволяет нам это оценить, являются кадры из фильма «Папиросни-

19. Цит. по: Туловская Ю.А. Текстиль Авангарда. Рисунки для ткани. Екатеринбург: TATLIN, 2016. С. 51.

20. Указ. соч. С. 80. ца из Мосельпрома», который вышел на экраны в 1924 году. Платье с рисунком Варвары Степановой определённо выглядит вещью из другого мира, значительно контрастируя с обстановкой. Внимание художниц было приковано не только к самим рисункам, но и к специфике текстиля как такового. Степанова считала, что художнику нужно участвовать в производстве ткани на всех уровнях.

К сожалению, многим планам не суждено было воплотиться в жизнь. Уже в начале 30-х годов работы конструктивистов всё больше подвергаются критике, и на смену им приходит агитационный текстиль социалистического реализма. Кроме того, несмотря на манифесты и установки, как бы ни пытались художницы отрицать роль моды в социуме, но в процессе творчества художник брал верх над производственником, а чрезмерная унификация сталкивалась с рядом противоречий. Вероятно, с этим связаны слова Варвары Степановой в 1929 году: «Ошибочно думать, что мода является лишь ненужным придатком спекулятивного характера» ${ }^{21}$.

Идея авангарда о существовании художника-творца, способного создать новую систему жизни, не была доведена до конца, а возможно, и вовсе потерпела неудачу. Тем не менее опыты «амазонок авангарда» в области моды играют исключительно важную роль как для истории искусствоведения, так и для истории моды. Отсылки к их идеям были массово воспроизведены в 1960-х годах, а кроме того, появляются на подиуме до сих пор, вдохновляя творцов во всех областях искусства.

21. Стриженова Т.К. Из истории советского костюма. М.: Советский художник, 1972. С. 97.

\section{БИБЛИОГРАФИЯ}

1. Адаскина, Н.Л. Любовь Попова. Путь становления художника-конструктора / Н. Л. Адаскина // Техническая эстетика. 1978. № 10. С. 17-23.

2. Амазонки авангарда. Сб. статей под ред. Г. Ф. Коваленко. М.: Наука, 2001. 338 с.

3. Авангард-театр-мода. Каталог экспозиции. М.: Северный паломник, 2019.

4. Бакст, Л.С. Пути классицизма в искусстве / Л.С. Бакст // Аполлон. 1909. № 2-3.
5. Бартлетт, Дж. FashionEast: призрак, бродивший по Восточной Европе / Джурджа Бартлет; пер. с англ. Е. Кардаш / М.: Новое литературное обозрение, 2011. 356 c.

6. Горбова, Е.Н. Идеи жизнестроительства Русского авангарда в эстетике проекта «прозодежды» начала XX века / Е.Н. Горбова, О.Ю. Астахов // Вестник Казанского государственного университета культуры и искусств. 2012. № 1-3. С. 52-55. 
7. Зданевич, И. Почему мы раскрашиваемся / И. Зданевич, М. Ларионов // Аргус. 1913. № 12. С. 115-118.

8. Лаврентьев, А.Н. Производственный костюм и мода / А.Н. Лаврентьев // Художник, вещь, мода: Сб. статей; Сост. М.Л. Бодрова, А.Н. Лаврентьев. М.: Советский художник, 1988. 366 с.

9. Адаскина Н.Л., Краснянская К., Костаки А. Любовь Попова. Форма. Цвет. Пространство. М.: Кучково поле, Музеон, 2019. 256 с.: 256 ил.

10. Памяти Л. С. Поповой. [Некролог] // ЛЕФ. № 2. 1924. С. 3-4.

11. Родченко, А. Опыты для будущего / А. Родченко. М.: Грантъ, 1996. 416 с.

12. Степанова, В. Ф. Костюм сегодняшнего дня - Прозодежда. [Электронный ресурс] / В.Ф. Степанова // Леф. 1923. № 2. [Сетевой ресурс] URL: http://www. ruthenia.ru/moskva/origins/design/varst.htm

13. Стриженова, Т.К. Из истории советского костюма / Т.К. Стриженова. М.: Советский художник, 1972. 110 с.

14. Темерин, С.М. Русское прикладное искусство. Советские годы. Очерки / С. М. Темерин. М.: Советский художник, 1960. 458 с.
15. Туловская, Ю.А. Текстиль авангарда. Рисунки для ткани / Ю. А. Туловская. Екатеринбург: TATLIN, 2016. $173 \mathrm{c}$.

16. Хан-Магомедов, С.О. Пионеры советского дизайна / С. О. Хан-Магомедов. М.: Галарт, 1995. 423 с.

17. Bartlett, D. «Léon Bakst and Fashion: Beyond and After the Ballets Russes», Costume, vol. 52, no. 2, pp. 210-234 DOI: $10.3366 /$ cost.2017.0025

18. Tiramani, J. 2015. "Janet Arnold's Patterns of Fashion», Costume, vol. 49, no.2, pp. pp. 186-197 DOI: 10.1179/0590887615z.00000000075

19. Ng, S. 2015. «Gendered by Design: Qipao and Society, 1911-1949», Costume, vol. 49, no.1, pp. 55-74 DOI: 10.1179/0590887614z.00000000063 (in English)

20. Pecorari, M. 2019.» Fashion archives, museums and collections in the age of the digital», Critical Studies in Fashion \& Beauty, vol. 10, no. 2, pp. 3-29 DOI: 10.1386/ csfb.10.1.3_7 (in English)

21. Kuldova, T. 2014.» Fashion exhibition as a critique of contemporary museum exhibitions: The case of 'Fashion India: Spectacular Capitalism», Critical Studies in Fashion \& Beauty, vol. 5, no. 2, pp. 313-336 DOI: 10.1386/csfb.5.2.313_1 (in English) 